\title{
Os Direitos Humanos Trabalhistas dos Contratados de Agências Internacionais atuantes na Crise Migratória no Estado de Roraima
}

\author{
Labor Human Rights of Non-Staff Personnel of Pro-Migrants \\ International Agencies acting in the Migration Crisis in the State of \\ Roraima, Brazil
}

Fernando César Costa Xavier ${ }^{1}$

\begin{abstract}
Resumo: As Organizações Internacionais são protegidas internacionalmente por imunidades e privilégios jurídicos, sendo que, no Brasil, os tribunais superiores reconhecem que essa proteção é absoluta, inclusive no âmbito jurisdicional. Isso significa dizer que elas têm o direito de não responder à Justiça brasileira em qualquer hipótese, inclusive em questões relacionadas aos contratos de trabalho que elas celebram com seus empregados. Ao desenvolverem suas missões institucionais no território de algum país, é bastante frequente a contratação de pessoal local, principalmente para o desempenho de tarefas ordinárias de consultoria e serviços especiais. Em Roraima, desde que a crise migratória venezuelana se agravou, a partir de meados de 2016, algumas agências internacionais - OIM, ACNUR, UNFPA, UNICEF, ONU Mulheres e PNUD - instalaram-se no Estado, surgindo daí uma oferta de empregos inteiramente nova. Muitas pessoas que vivem na capital roraimense passaram a ser recrutadas por essas agências, à medida que elas ampliavam sua base de atuação, para trabalhar tanto nas sedes dos escritórios quanto nos abrigos para refugiados nas cidades de Boa Vista e Pacaraima. Até hoje, a maioria absoluta dos recrutados foi admitida sob modelos de contrato que não lhes assegura a condição de membros do staff; não são, portanto, tecnicamente, "funcionários" dessas agências. A imunidade absoluta de jurisdição que é assegurado às organizações internacionais faz com que o respeito aos direitos trabalhistas das pessoas contratadas ou empregadas dependa enormemente do cumprimento de boa-fé dos princípios e normas internas adotados pelas agências internacionais. A preocupação com esse cenário assume ainda maior relevância quando se recorda que muitos dos direitos trabalhistas frequentemente cobertos por contratos de trabalho, ao menos no Brasil, estão garantidos em instrumentos internacionais de direitos humanos. O fato de que as atividades laborais em Roraima são desenvolvidas em um contexto de emergência torna ainda mais desafiador o propósito de respeito
\end{abstract}

1 Professor Associado do Instituto de Ciências Jurídicas, da Universidade Federal de Roraima (ICJ/UFRR). Professor do Curso de Direito da Universidade Estadual de Roraima (UEER). Doutor em Relações Internacionais pela Universidade de Brasília (UnB). Doutorando em Sociologia e Direito pela Universidade Federal Fluminense (UFF). Mestre em Direito pela Universidade Federal do Pará (UFPA). Graduado em Direito pela Universidade Federal do Pará (UFPA). Membro da Comissão Especial de Direito Internacional do Conselho Federal da OAB. 
a condições justas, equitativas e satisfatórias de trabalho. Embora não se tenha tornado notório qualquer caso de término de contrato de trabalho executado em Roraima em que um contratado saiu dos quadros da organização internacional sentindo-se lesado em seus direitos e garantias, a mera possibilidade de isso vir a ocorrer algum dia acende a luz para um cenário constrangedor. Em contextos de crises migratórias, como o de Roraima, a preocupação com os direitos humanos não deve estar adstrita apenas aos próprios migrantes, mas também àqueles que trabalham diariamente protegendo-os, pois que, afinal, eles também podem estar em alguma condição de vulnerabilidade que ameace alguns de seus direitos humanos.

Palavras-chave: Agências Internacionais. Imunidade Jurisdicional. Pessoal Non-Staff. Direitos Humanos Trabalhistas. Roraima

Abstract: International Organizations are protected internationally by immunities and legal privileges; in Brazil, high courts recognize that this protection is absolute, including in the jurisdictional scope. This means that they have the right not to respond to the Brazilian judicial bodies in any case, including issues related to employment contracts entered into with their employees. When carrying out their institutional missions in the territory of a country, it is quite common to hire local personnel, mainly for the performance of ordinary consultancy tasks and special services. In Roraima, since the Venezuelan migratory crisis worsened, as of mid-2016, some international agencies - IOM, UNHCR, UNFPA, UNICEF, UN Women and UNDP - have settled in the State, creating an entirely new job offer. Many people living in the capital of Roraima were recruited by these agencies, as they were expanded their operations, to work both in the headquarters of the offices and in shelters-camp for refugees in the cities of Boa Vista and Pacaraima. To date, the absolute majority of recruits has been admitted under contract models that do not guarantee them the status of staff members; therefore, they are not technically "staff personnel" of these agencies. The absolute immunity from jurisdiction that is guaranteed to international organizations means that respect for the labor rights of persons hired or employed depends enormously on good faith compliance with the internal principles and standards adopted by international agencies. The concern with this scenario takes on even greater relevance when it is recalled that many of the labor rights frequently covered by employment contracts, at least in Brazil, are guaranteed in international human rights instruments. The fact that work activities in Roraima are carried out in an emergency context makes the purpose of respecting fair, equitable and satisfactory working conditions even more challenging. Although no case of termination of an employment contract executed in Roraima in which a contractor was dismissed from an international organization and felt injured in his rights and guarantees has become notorious, the mere possibility that this will ever happen turns on the light for an embarrassing scenario. In contexts of migratory crises, such as that of Roraima, the concern with human rights should not be restricted only to the migrants themselves, but also to those who work daily to protect them, as they may also be in some condition of vulnerability that threatens some of their human rights.

Keywords: International Agencies. Jurisdictional Immunity. Non-Staff Personnel. Labor Human Rights. Roraima. 


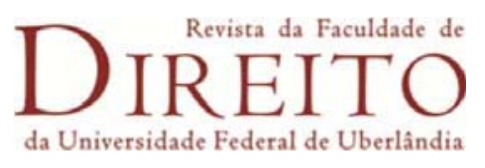

"Ainda que, do ponto de vista jurídico, as organizações do sistema das Nações Unidas não estejam sujeitas, em princípio, aos códigos trabalhistas nacionais e aos princípios internacionais do trabalho, elas não podem se esconder atrás de seus privilégios e imunidades e continuar a usar indevidamente contratados que não serão tratados como funcionários. Não é honesto, por um lado, defender os direitos humanos, altos princípios e conceitos como 'trabalho decente', ou outros incluídos no Pacto

Global, enquanto, por outro lado, cria-se uma força de trabalho vulnerável sob condições trabalhistas que frequentemente não atendem localmente aos padrões laborais estabelecidos nos mesmos países onde as operações ocorrem".

\section{Introdução}

Ainda que o boom migratório de venezuelanos para o Brasil, a partir de 2016, tenha trazido consigo o drama humanitário típico dos casos de êxodo forçado - especialmente para Roraima, epicentro da crise migratória ele também revelou oportunidades interessantes para a população local. Desde os primeiros momentos, muitos comerciantes lucraram com a chegada de venezuelanos desesperados por produtos de consumo diário que haviam desaparecido das prateleiras em suas cidades. Migrantes com boa formação escolar e técnico-profissional aqueceram a oferta de mão-de-obra, principalmente no setor de serviços; e muitos deles, para evitar o desemprego, foram trabalhar em supermercados e restaurantes desempenhando atividades menos complexas do que aquelas para as quais seus currículos os qualificavam. O setor imobiliário, com destaque para o aluguel de apartamentos e quitinetes nos bairros na zona oeste da capital roraimense, também foi estimulado pelos contingentes de migrantes que foram chegando sem cessar.

Esses efeitos específicos do incremento demográfico, contudo, não eram propriamente inauditos. Nas décadas de 60 e 70 do séc. XX, quando Roraima ainda era um território federal, ondas migratórias internas, em 
especial de pessoas vindas do Nordeste brasileiro, adensaram as taxas demográficas e fizeram com que as áreas urbanas se expandissem desordenadamente. O fenômeno do aumento populacional seguiu dando saltos após a transformação do território em Estado (ente estadual), com o advento da Constituição de 1988. Nas décadas seguintes, pessoas de outros Estados foram chegando, e, em pouco tempo, muitas delas estavam dominando determinadas áreas na política, nos empreendimentos privados e no funcionalismo público. Nesses períodos de migração interna, o mercado de trabalho e o setor imobiliário experimentaram franco crescimento.

Assim, o aumento populacional irrefreado que é causado atualmente pela migração venezuelana, ainda que seja muito mais impactante, em termos proporcionais, do que aquele das migrações internas do passado, não deixa de ser, em todo caso, uma nova etapa de um fenômeno um tanto familiar. Entretanto, há um elemento relacionado à natureza involuntária da migração internacional venezuelana que a torna qualitativamente distinta. Por não se tratar de um processo migratório planejado ou induzido pelas autoridades públicas, como o foram as migrações internas, sendo antes uma migração forçada (CIDH, 2018), causada pela falência de um regime político, ela se tornou descontrolada a partir de um certo momento, exigindo então planos de ação ousados dos Estados e entes intergovernamentais concernidos. E precisamente esses planos de ação abriram portas - estas, sim, inauditas.

Em um estágio crítico da migração, no dia 12 de junho de 2017, instalou-se em Roraima um escritório do Alto Comissariado das Nações Unidas - ACNUR, o primeiro órgão da Organização das Nações Unidas a se fixar no Estado para acompanhar o processo de deslocamento de venezuelanos. Em agosto do mesmo ano, chegaram mais duas agências internacionais, o Fundo de População das Nações Unidas - UNFPA (órgão da ONU) e a Organização Internacional para as Migrações - OIM. Vieram ainda, nos anos seguintes, o Fundo das Nações Unidas para a Infância - 


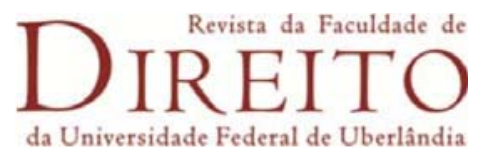

UNICEF (maio de 2018), o ONU Mulheres (novembro de 2018) e o Programa das Nações Unidas para o Desenvolvimento - PNUD² (janeiro a dezembro de 2019), todos estes órgãos da ONU³ .

A chegada dessas agências internacionais representou para muitos profissionais locais um leque de oportunidades ${ }^{4}$. O caso mais ilustrativodisso é o dos bacharéis em relações internacionais formados pela Universidade Federal de Roraima. À vista da ênfase do curso na área de diplomacia, não havia chances reais de empregabilidade em Roraima para os internacionalistas recém-formados, mesmo com o Estado situado na tríplice fonteira Brasil-Venezuela-Guiana. Os que não queriam desperdiçar o diploma tinham que buscar oportunidades fora de Roraima, ou tentar alguma ocupação acadêmica na própria universidade. As pessoas formadas em outras áreas, como jornalismo, psicologia, serviço social etc., também enfrentavam dificuldades, no caso delas mais relacionadas com quadros de saturação no mercado de trabalho. Nesse cenário, apareceram as organizações internacionais ofertando vagas de trabalho que pareciam uma chance de ouro.

2 Diferentemente dos outros órgãos da ONU, o PNUD não abriu um escritório em Roraima, mas apenas implementou localmente dois projetos sobre inserção econômica dos migrantes e desenvolvimento. Outras organizações, como a Organização Internacional do Trabalho (OIT) e a Organização Pan-Americana de Saúde (OPAS), realizaram atividades em Roraima vinculadas à acolhida humanitária de venezuelanos, porém não fixaram base operacional.

3 A ONU e a OIM são organizações internacionais, criadas por tratados, com personalidade jurídica própria. O Brasil é parte nessas organizações porque ratificou os seus tratados constitutivos, respectivamente, a Carta da ONU (Decreto 19.841, de 1945) e a Constituição da OIM (Decreto 8.101, de 2013). UNFPA, UNICEF, ONU Mulheres e PNUD, por sua vez, são órgãos que compõem a estrutura da ONU, entidades especializadas que atuem em seu nome em conformidade com a Carta da ONU e que, conforme se verá, recebem a denominação usual de "agências".

${ }^{4}$ É verdade que também vieram para Roraima inúmeras organizações não-governamentais, como a Fraternidade - Federação Humanitária Internacional, a Associação Voluntários para o Serviço Internacional - AVSI Brasil, o Conselho Norueguês de Refugiados, os Médicos Sem Fronteira - MsF, o Serviço Jesuíta para Migrantes e Refugiados - SJMR, a Agência Adventista de Desenvolvimento e Recursos Assistenciais - ADRA e tantas outras entidades sem fins lucrativos, e todas igualmente ofereceram localmente ofertas de emprego. Mas elas não gozam de imunidade de jurisdição do Brasil, e podem ser processadas na esfera trabalhista. Desse modo, elas escapam ao enfoque do presente artigo. 
A empolgação que sucedeu, no entanto, fez com que passasse despercebido um importante aspecto que torna a oportunidade de trabalhar em uma organização internacional menos reluzente. Organizações internacionais, a exemplo da ONU e de suas agências, não são regidas pelas leis trabalhistas dos países onde exercem suas atividades, e, em qualquer caso, essas entidades intergovernamentais podem não aceitar ser julgadas nos órgãos judiciais nacionais. Isso quer dizer que as novas ofertas de empregos surgidas na fronteira brasileira com a Venezuela teriam, como elemento inconveniente para os empregados, uma aparente desproteção nas situações em que pudessem se sentir injustiçados ou prejudicados na relação de trabalho.

Embora todos os empregados, os de Roraima e os de fora, estejam sob essa mesma situação de desproteção nos seus contratos de trabalho, não podendo contar com as leis e tribunais nacionais, não seria incorreto pressupor que estão em uma posição ainda mais delicada, lidando com uma experiência laboral nova e complexa, os trabalhadores contratados localmente, inclusive os cidadãos venezuelanos que passaram a residir em Roraima e foram contratados por algumas dessas organizações.

Tendo esse pano de fundo, o artigo se propõe a chamar a atenção para uma certa invisibilidade que há para essas pessoas que foram contratadas e estão trabalhando arduamente na defesa dos direitos humanos dos migrantes. Os direitos delas (direitos trabalhistas e de seguridade social) também estão em jogo, e esses direitos são direitos humanos que, sem dúvidas, merecem uma proteção tão dedicada quanto aquela conferida para os direitos humanos dos migrantes que essas pessoas assistem na sua rotina laboral.

Este artigo buscou ir além de um debate meramente jurídico, adstrito aos aspectos da contratação por organizações internacionais e os direitos 


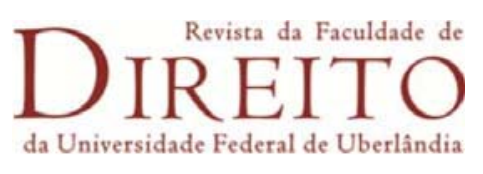

nela envolvidos, embora esta parte seja muito importante ${ }^{5}$. A contribuição maior talvez esteja a cargo da pesquisa empírica encaminhada. Com algum esforço, foram levantados alguns dados referentes ao quantitativo geral de indivíduos que atuaram e atuam nas organizações instaladas em Roraima.

A coleta de dados em casos como este não é fácil. De forma compreensível, mas em certo sentido curiosa, os escritórios das organizações são discretos quanto às informações sobre os seus recursos humanos e a forma como eles são geridos. Aos pesquisadores interessados em detalhes impõe-se um desestimulante conjunto de exigências burocráticas.

No presente caso, foi preciso ir atrás primeiramente de dados primários sobre as contratações, os quais foram obtidos através de entrevistas semi-estruturadas realizadas com pessoas contratadas ou excontratadas. As entrevistas não se detiveram em nada que pudesse ser considerado realmente sigiloso. $\mathrm{O}$ foco era verificar se essas pessoas conheciam ou se foram adequadamente informadas sobre determinados aspectos de seus regimes de trabalho ou sobre as garantias deles decorrentes. Os ricos relatos fornecidos por elas, que optaram por não se identificar, forneceu um quadro com contornos suficientemente claros, que permitiram levar adiante a hipótese de que os direitos trabalhistas de que aqui se cuida são comumente negligenciados e, via de regra, encontram-se ameaçados.

Há, é verdade, riscos inerentes aométodo de pesquisa escolhido, tais como o fornecimento de informações e dados desatualizados ou mesmo equivocados, a partir de impressões pessoais que não corresponderiam à realidade dos fatos; como se sabe, relatos subjetivos costumam assumir vieses particulares, alimentados por crenças e ideologias. À vista disso, a

5 Nessa parte, merece destaque o ótimo livro "The Duty of Care of International Organizations Towards Their Civilian Personnel Legal: Obligations and Implementation Challenges" ["O Dever de Cuidado das Organizações Internacionais em Relação ao seu Pessoal Civil: Obrigações e Desafios de Implementação", em tradução livre], editado por professores italianos e utilizado como principal referência bibliográfica. 
presente pesquisa poderia ser caracterizada como exploratória em um sentido bastante modesto.

A estruturação dos capítulos foi inspirada e segue orientada pela citação utilizada na epígrafe do artigo. A primeira parte recorda a imunidade das organizações internacionais no plano nacional, e também aproveita para esclarecer o uso de algumas terminologias, em especial "agência internacional"; a segunda parte apresenta os modelos e categorias adotados para os funcionários das agências internacionais, dentre os quais os membros non-staff são identificados como especialmente vulneráveis; a terceira é uma parte intermediária para falar da tensão entre o dever de cuidado que as organizações devem ter com o seu pessoal e a exigência de sacrifícios imposta sobre esse pessoal no desempenho do serviço humanitário emergencial; a quarta reflete sobre como alguns aspectos dos contratos trabalhistas com as agências conflitam com padrões laborais nacionais; e, por fim, a quinta parte examina o quanto é desconcertante que as mesmas entidades intergovernamentais que estão investidas da responsabilidade de promover direitos humanos e inclusão social não façam o dever de casa, permitindo a vulneração de direitos humanos de uma parte importante de seu próprio pessoal.

\section{As organizações internacionais do sistema ONU têm} privilégios e imunidades e não estão sujeitas às leis trabalhistas nacionais

Com a proliferação de organizações internacionais após a Segunda Guerra, muitos países que haviam participado da criação da ONU adiantaram-se para resolver em seus sistemas legais domésticos qual seria a condição jurídica desses entidades intergovernamentais (e a de seus funcionários) quando estivessem atuando nos seus territórios.

Em fevereiro de 1946, foi promulgada, em Londres, a Convenção sobre Privilégios e Imunidades das Nações Unidas, que, em seu art. II, Seção 2, 
consagrou no direito internacional o regime das imunidades: "A Organização das Nações Unidas, seus bens e haveres, qualquer que seja a sua sede ou o seu detentor, gozarão da imunidade de jurisdição, salvo na medida em que a Organização tiver a ela renunciado em determinado caso"6. Anos depois, a Convenção sobre Privilégios e Imunidades das Agências Especializadas das Nações Unidas ${ }^{7}$ estendeu os privilégios e imunidades da ONU para as suas agências, unificando o regime de imunidades para as organizações internacionais lato sensu.

Isso não impediu que, tempos depois, as imunidades delas fossem desafiadas. Há vários casos em que essas imunidades restaram relativizadas, v.g., no recente caso Jam et al v. International Finance Corp., em que a Suprema Corte dos Estados Unidos decidiu que organismos internacionais sob a forma de instituições financeiras, como o Banco Mundial e o Banco Interamericano de Desenvolvimento, podem ser processados internamente quando seus investimentos em projetos de desenvolvimento causem algum dano para comunidades locais (UNITED STATES SUPREME COURT, 2019).

O costume internacional de relativização da imunidade jurisdicional dos Estados, abrindo a possibilidade de que eles passassem a ser processados pela prática de atos de natureza privada (atos de gestão), animou ainda mais a ideia de que a imunidade das organizações internacionais poderia, também ela, admitir exceções.

No Brasil, o Tribunal Superior do Trabalho (TST) e o Supremo Tribunal Federal (STF) foram instados a julgar essa questão, e o entendimento que prevaleceu foi o de que, diferentemente dos Estados, cuja imunidade de jurisdição poderia ser relativizada, as organizações internacionais possuíam uma imunidade de tipo absoluta, o que incluía, por

\footnotetext{
${ }^{6}$ A Convenção foi ratificada pelo Brasil por meio do Decreto 27.784, em 1950.

${ }^{7}$ Ratificada pelo Brasil em 1963, pelo Decreto 52.288.
} 
ONU (v.g., Recurso de Embargos em Embargos de Declaração em Recurso de Revista 17440-79.2007.5.20.0002, julgado em 07 nov. 2019).

Nesses e em vários outros casos sobre a mesma matéria, foi recordada, no TST, a Orientação Jurisprudencial n $\mathrm{n}^{\circ} 416$, da Subseção I Especializada em Dissídios Individuais, definida pelo Tribunal Pleno em 23 de maio de 2016: "As organizações ou organismos internacionais gozam de imunidade absoluta de jurisdição quando amparados por norma internacional incorporada ao ordenamento jurídico brasileiro [...]”.

Isso não quer dizer que esses organismos atuem em um limbo legal, sem obedecer a quaisquer regras, inclusive sobre contratação e empregabilidade de seus recursos humanos. Andrea de Guttry lembra que "As relações contratuais de trabalho entre um indivíduo e a organização internacional que o recruta são, de modo geral, reguladas pelo direito interno da organização internacional e pelos princípios gerais de direito" (de Guttry, 2018, p. 74). O Tribunal Administrativo da Organização Internacional do Trabalho (ILOAT), sediado em Genebra, mantém-se como órgão competente para julgar queixas trabalhistas de indivíduos contra organizações internacionais, conquanto existam também órgãos administrativos de resolução de controvérsias na estrutura das próprias agências internacionais.

Em tempo, não se pode esquecer que as organizações podem ser processadas judicialmente no âmbito nacional em casos excepcionais, conforme previsto nas convenções internacionais regentes, desde que elas expressamente renunciem à imunidade a que têm direito. No caso das organizações em Roraima, ACNUR, UNFPA, ONU Mulheres, PNUD ou OIM, nenhuma delas expressou qualquer renúncia.

Embora prevista em tratados e delineada em decisões de tribunais superiores, a imunidade que possuem as organizações intergovernamentais não é tão conhecida, mesmo por juristas e pessoas que trabalham há algum tempo nessas organizações. E os que sabem dela não têm tanta certeza se 
ela vale apenas para a ONU e suas agências ou para as organizações internacionais em geral. Algumas decisões alimentam a confusão, como aquela tomada pelo TST em fins de 2019, no Recurso Ordinário 14769.2017.5.23.0000, em que a entidade demandada era o Instituto Interamericano de Cooperação para a Agricultura (IICA):

[...] Fazendo coro a este entendimento, igualmente, em 16 de junho de 2017, a matéria veio à tona naquela excelsa Corte, no julgamento do RE 10348-40, ocasião em que o Plenário decidiu por reconhecer a existência de repercussão geral da questão constitucional e, por maioria, reafirmou-se a jurisprudência dominante sobre a matéria. [...] no caso, a Convenção sobre Privilégios e Imunidades das Nações Unidas (Decreto 27.784/1950) e a Convenção sobre Privilégios e Imunidades das Agências Especializadas das Nações Unidas (Decreto 52.288/1963) regulam os casos outorgados pelo Brasil à ONU e aos seus órgãos, incluindo a imunidade de jurisdição. Assim, há norma expressa em convenção internacional ratificada pelo Brasil, na qual é conferida imunidade de jurisdição e de execução à ONU-Organização das Nações Unidas, a que se vinculam a FAO-Organização das Nações Unidas para a Alimentação e Agricultura e o executado IICAInstituto Interamericano de Cooperação para a Agricultura. (BRASIL, 2019).

Veja-se que a ementa do julgado, remetendo à decisão do STF no RE 10348-40, cita a Convenção sobre Privilégios e Imunidades das Agências Especializadas das Nações Unidas e, em seguida, conclui pela sua aplicação ao IICA, enquadrando-o como órgão vinculado à ONU.

A citada Convenção, em seu art. 1’o $1^{\text {a }}$ Seção, II, 'a' a ‘j', contém um índice não-exaustivo das agências especializadas da ONU: a Organização Internacional do Trabalho (OIT); a Organização das Nações Unidas para a Alimentação e a Agricultura (FAO); a Organização das Nações Unidas para a Educação, a Ciência e a Cultura (UNESCO); a Organização da Aviação Civil Internacional; o Fundo Monetário Internacional (FMI); o Banco Internacional para a Reconstrução e o Desenvolvimento (BIRD); a Organização Mundial de Saúde (OMS); a União Postal Universal (UPU); a União Internacional de Telecomunicações (UIT), além de outras entidades criadas com fundamento nos arts. 57 e 63 da Carta da ONU. 


\section{DIREITO}

$\mathrm{O}$ art. 57 da Carta diz que as organizações criadas por acordos intergovernamentais para atuar de forma especializada nos campos econômico, social, cultural, educacional, sanitário e conexos, serão vinculadas às Nações Unidas, e poderão ser designadas como "entidades especializadas" da ONU. O art. 63 trata do papel do Conselho Econômico e Social da ONU para firmar acordos com essas agências especializadas, com vistas a determinar as condições em que elas serão vinculadas às Nações Unidas.

Em Roraima, convencionou-se chamar as entidades todas - ACNUR, UNFPA, UNICEF, ONU Mulheres, PNUD e OIM - de "agências"9. Não deve haver dúvidas razoáveis em relação ao uso do termo para a maioria delas, mas talvez apenas para a OIM, já que é uma organização internacional independente, e não um órgão da ONU, como é o caso das demais. É verdade que eventual dúvida já teria sido afastada desde setembro de 2016, quando a ONU celebrou acordo com a OIM formalizando a adesão desta ao sistema das Nações Unidas, reconhecendo-a assim como "agência especializada" (GUEVANE, 2016).

Sobre a condição de "agência" em relação a outras organizações internacionais de cooperação apartadas do sistema ONU (principalmente, as iniciativas regionais), isso seria irrelevante para o escopo presente, tanto porque não são entidades desse tipo as que estão instaladas em Roraima, quanto porque a imunidade tratada neste tópico parece ter sido ampliada pelos tribunais para as organizações em geral, independentemente de pertencerem ao sistema das Nações Unidas, indo-se assim além de uma interpretação mais literal das Convenções. À vista disso, o termo "agência"é adotado livremente neste artigo - valendo tanto para os órgãos da ONU (ACNUR, UNFPA, UNICEF, ONU Mulheres e PNUD) quanto para a OIM -, mas não sem descartar as ressalvas acima.

\footnotetext{
9 UFRR e agências da ONU no Brasil inauguram Centro de Referência para Refugiados e Migrantes em Roraima (UFRR, 2018).
} 
Compreendida a imunidade em favor das organizações internacionais, convém agora mostrar mais de perto como elas, cientes ou não da "blindagem" de que dispõem, têm implementado seus modelos de contratação de recursos humanos.

\section{Os funcionários e os contratados que não serão tratados como funcionários: a força de trabalho sombria e silenciosa.}

Ao chegarem a Roraima, a partir de 2017, as organizações internacionais trouxeram para montar seus escritórios pequenas equipes, uma ou duas pessoas, que foram incumbidas de dar os passos iniciais no esforço de gestão conjugada da crise migratória. Se de um lado traziam a expertise na gestão humanitária, de outro tinham pouco ou nenhum conhecimento das peculiaridades do extremo norte do Brasil. Os traços biotípicos dos funcionários, bem distintos do padrão local, bem como as vestimentas (camisas e coletes das agências que representavam) e sotaques, faziam com que eles, em seus grupos ainda pequenos e sempre coesos, fossem facilmente reconhecidos como "de fora" por onde passavam. As equipes das diferentes agências criaram laços entre si, e o termo "interagências" passou a ser largamente usado para designar o amplo grupo de recém-chegados que passaram a compartilhar espaços de trabalho e de lazer.

Nos primeiros meses, os residentes locais ainda não haviam obtido qualquer vaga de trabalho, ainda que tenham sido anunciados publicamente processos de seleção. Uma das pessoas ouvidas nesta pesquisa sustenta que há uma política implícita de se contratar preferivelmente gente de fora, pelo menos para os cargos mais importantes. Tanto seja, o quadro foi mudando rapidamente, em parte porque as agências todas montaram seus escritórios 
em prédios da Universidade Federal de Roraima ${ }^{10}$, e, nas negociações estabelecidas para isso, a cessão não-onerosa dos prédios deveria ser retribuída, dentre outras formas, com a absorção em seus quadros de estudantes e egressos da universidade.

Dois anos após a chegada, já em 2019, o cenário ficou bastante diferente. Havia então mais de 160 pessoas trabalhando para as agências (ver tabela abaixo), muitas delas oriundas não apenas da Universidade Federal, mas também de outras instituições de ensino superior locais. Embora se acreditasse que, para o ano de 2020, com o arrefecimento do fluxo migratório e a realocação do comando da força-tarefa de acolhimento de migrantes para Manaus, o número de pessoas contratadas diminuiria sensivelmente, isto não ocorreu até o momento. Com exceção do PNUD (ver nota 1), as demais agências ampliaram o número de funcionários recrutados, conforme se vê abaixo:

Tabela 1 - Estimativa geral de pessoas trabalhando nas agências internacionais em Roraima *

\begin{tabular}{|c|c|c|}
\hline Agência internacional & $\begin{array}{c}\text { Número de pessoas } \\
\text { (junho de 2019) }\end{array}$ & $\begin{array}{c}\text { Número de pessoas } \\
\text { (janeiro de 2020) }\end{array}$ \\
\hline ACNUR & 64 & 72 \\
\hline OIM & 72 & 120 \\
\hline UNFPA & 13 & 8 \\
\hline UNICEF & 9 & 9 \\
\hline ONU Mulheres & 2 & 3 \\
\hline PNUD & 2 & - \\
\hline Total & $\mathbf{1 6 2}$ & $\mathbf{2 1 2}$ \\
\hline
\end{tabular}

Fonte: elaboração própria.

Os quantitativos acima incluem, indiscriminadamente, todos os que trabalham para as agências, excluídos apenas estagiários e voluntários. Ainda não foi possível precisar, nesse quantitativo, quantos pertencem a

${ }^{10}$ No início, ACNUR, OIM, UNFPA e ONU Mulheres se instalaram no prédio do Núcleo Amazônico de Pesquisa em Relações Internacionais - NAPRI, o UNICEF no bloco Direito e Música, e posteriormente alguns ampliaram sua base de apoio para o Centro de Referência para Refugiados e Migrantes, também no campus universitário. 
cada um dos modelos e categorias que existem para o pessoal das organizações do sistema ONU, isto é, quantos podem efetivamente ser considerados "funcionários" das agências.

Os modelos de contratação de pessoal podem variar conforme as agências, sendo complexos e diversos os status que podem ter o indivíduo que desempenha funções nelas. Em todo caso, há uma diferença fundamental, a "questão central" (BRINO, 2018, p. 155) entre o status dos trabalhadores, isto é, saber se eles estão contratados para integrar a equipe principal (staff) ou não (non-staff).

Os funcionários do staff, recrutados internacional ou nacionalmente, podem desempenhar desde atividades de gestão ou atividades profissionais especializadas até serviços gerais sob a forma de tarefas de apoio (serviços administrativos, de secretariado e de escritório). As distintas categorias dos membros dostaff, cada qual com níveis de responsabilidade e exigências específicos, podem ser listadas como: Categorias profissionais e superiores (P e D), Serviço geral e categorias relacionadas (G, TC, S, PIA, LT), Oficiais Profissionais Nacionais (NO), Serviço de campo (FS) e Nomeações Seniores (SG, DSG, USG e ASG) (Creta, 2018, p. 181). Os contratos internacionais estão ligados aos Professional contracts (P) e Higher category contracts (D), enquanto os contratos nacionais à categoria de serviços gerais (G) e demais categorias (TC, S, PIA, LT).

$\mathrm{O}$ art. $6^{\circ}, 18^{\mathrm{a}}$ Seção, da Convenção sobre Privilégios e Imunidades das Agências das Nações Unidas, dispõe que cada agência deve especificar as categorias de funcionários a quem serão conferidos direitos e garantias equiparáveis às dos funcionários de missões diplomáticas; na prática, eles são conferidos aos funcionários do staff internacional. Isso terá especial relevância para se determinar, por exemplo, os casos de incidência tributária sobre rendimentos auferidos ${ }^{11}$.

${ }^{11}$ Em um precedente de 2009, o Superior Tribunal de Justiça entendeu que: "A Convenção
sobre Privilégios e Imunidades das Nações Unidas estabelece os privilégios e imunidades 


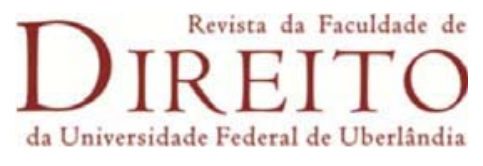

Os procedimentos de contratação relacionados ao staff são, no geral, rigorosos e demorados. Em Roraima, como se disse, a maioria dos funcionários que integram o staff das agências vieram de fora e muitos têm anos de experiência acumulados. Um aumento da demanda pelos serviços humanitários prestados, entretanto, passou a exigir a contratação de mais funcionários, tendo então as agências, como de praxe, optado por modelos de contratação mais flexíveis, com processos de seleção mais diretos e nos quais os contratados possam se apresentar imediatamente ("As soon as possible"). Sendo mais simplificados, nem por isso são tão simples assim.

Em verdade, a aplicação das candidaturas às agências, inclusive para as categorias non-staff, é um processo relativamente intrincado. É necessário aos interessados que preencham um extenso e detalhado formulário (Formulário P11) - às vezes escrito todo em inglês, mesmo quando os idiomas requeridos para o candidato são apenas português e espanhol ${ }^{12}-$, o qual deve ser encaminhado para algum correio eletrônico. Se o seu currículo e demais documentos (algumas vezes, pede-se carta de motivação e referências pessoais) chamarem a atenção, o aplicante é convidado para uma entrevista, após a qual terá que aguardar por alguns

dos Funcionários a serviço das Nações Unidas, dispondo em seu artigo V, que 'serão isentos de qualquer imposto sobre os salários e emolumentos recebidos das Nações Unidas' [...] Tal isenção, entretanto, não se estende aos técnicos contratados pela ONU, visto que este benefício não foi previsto no artigo VI, Sessão 22, que trata dos privilégios e imunidades conferidos aos técnicos, além de não possuírem a situação jurídica de funcionário [...] $\mathrm{A}$ pessoa física que não faz parte do quadro efetivo da ONU, prestadora de serviço a Programa desta Organização, como é o caso do PNUD, não goza de isenção sobre os rendimentos recebidos em razão do serviço prestado, sobre eles devendo incidir o imposto de renda, uma vez que importam em acréscimo patrimonial e não estão beneficiados por isenção" (REsp 1031259/DF, Rel. Ministro Francisco Falcão, $1^{\text {a }}$ Turma, julgado em 03/03/2009, DJe 03/06/2009). O precedente, todavia, é confuso porque fala de "técnicos", quando a Convenção sobre Privilégios e Imunidades das Nações Unidas está tratando, no dispositivo citado (art. VI, Sessão 22), de "peritos em missão"; apenas chama a atenção a conclusão de que a ausência de imunidade tributária dá-se em razão de os técnicos/peritos não serem tratados como "funcionários", como igualmente não o são os consultores individuais e contratados para serviços especiais.

${ }^{12}$ Ver, v.g., este Personal History Form do ONU Mulheres para a vaga de "Consultor/a Local - Liderança, empoderamento, acesso e proteção das mulheres em resposta à crise humanitária”, em Boa Vista: http://www.onumulheres.org.br/wp-content/uploads/2018/01/P _11_form_UNwomen.doc 
dias. Não obstante a chamada seja tornada pública, não há a divulgação do número de inscritos (aplicantes), nem do resultado final do certame. O selecionado é contactado diretamente pelo funcionário responsável pela seleção.

São diversas as modalidades de contratação de pessoal que atuará nas agências como uma categoria "móvel" - Vania Brino refere mais de 30 modalidades (2018, p. 157) -, que não integrará a equipe principal (i.e., será non-staff), p. ex., consultores, voluntários das Nações Unidas (UNVs), observadores militares, funcionários cedidos pelos governos etc., ou contratados para serviços especiais (Special Service Agreements) (TERZI; FALL, 2014). Uma das modalidades mais comuns, inclusive em Roraima, é a de consultores individuais (Individual Consultants), que são encarregados de entregar um determinado produto (serviço especializado) e incumbidos da apresentação de relatórios periódicos. Alguns autores, como Brino (2018, p. 157), listam os funcionários de staff nacional como sendo non-staff, talvez porque, na prática, eles sejam tratados como um status intermediário entre o staff internacional e o non-staff, e que acaba recebendo um tratamento mais aproximado deste segundo.

É notório que a política de empregamento nas organizações internacionais têm acompanhado o fenômeno mais global de flexibilização do mercado de trabalho nos últimos anos, o que faz com que os contratos temporários e o uso de consultores e contratados independentes, que constituirão uma parte significativa da categoria dos não-funcionários, sejam sempre uma opção válida (BRINO, 2018). O problema é que nem sempre esses contratos independentes são claramente "contratos de trabalho", perdidos que ficam em uma zona cinzenta na qual o vínculo empregatício é ofuscado por algo que se parece com um contrato de freelancer, um “emprego 'disfarçado”' (ULRICH, 2018, p. 261). 
Em Roraima, a ONU Mulheres contratou estagiários sob a forma de Special Service Agreements ${ }^{13}$, embora isso seja inusual para a própria agência. No caso da OIM, durante um longo tempo, ela utilizou em Roraima contratados individuais para trabalharem como horistas, por meio de um contrato "Special Short Term Hourly". São ainda poucos, proporcionalmente, os contratados localmente para o staff das agências ${ }^{14}$. A maioria absoluta integra o corpo de trabalhadores non-staff, quer dizer, os que não são tecnicamente funcionários das agências, ainda que compreendam uma parcela do pessoal que Brino (2018, p. 157) qualifica como um "força de trabalho sombria e silenciosa" das agências.

Há nas Nações Unidas uma preocupação crescente com o uso frequente e inadequado de pessoal non-staff, conforme se pode ler do relatório "Uso de pessoal non-staff e modalidades contratuais relacionadas nas organizações do sistema das Nações Unidas" (A/70/685), confeccionado pela Unidade de Inspeção Conjunta, a partir dos estudos de caso na República Democrática do Congo, no Haiti e na Índia, reportados por Cihan Terzi e Papa Louis Fall (2014). Nesse extenso e precioso relatório, é apontado que as organizações restam sendo afetadas pelo uso indevido de pessoal non-staff, não apenas em termos de perda de reputação, senão também em alta rotatividade, elevados custos administrativos, comprometimento de uma força de trabalho estável e motivada, aumento potencial de casos de fraude e corrupção, além de incremento potencial de desafios jurídicos (TERZI; FALL, 2014, p. 24).

Não obstante existam políticas em curso nas organizações internacionais que, para fins de proteção geral de seu pessoal, buscam

\footnotetext{
13 Ver em: http://www.onumulheres.org.br/wp-content/uploads/2019/06/20190618_TR_Esta gio_GiHA_Boa-Vista.pdf . Para estágios, a forma mais usual de contratação nas agências é de Intern/Internship.

14 O ACNUR, principalmente, representa uma exceção nesse caso. A agência prefere recrutar localmente para o staff nacional (G). No início de 2020, havia cerca de oito funcionários do staff internacional em Roraima, e mais que o triplo disso no staff nacional. Embora tenha evitado a contratação de horistas, sempre contou com o trabalho de estagiários, inclusive valendo-se de parceria com o Centro de Integração Empresa - CIEE.
} 


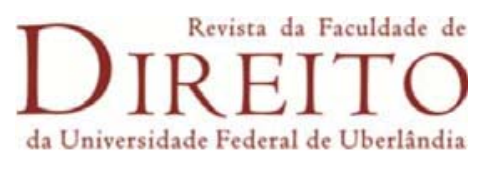

esvaziar a diferença entre staff e non-staff - como nos casos de enfrentamento do assédio no ambiente de trabalho (NADER; DUTRA, 2018) -, o cuidado das organizações ainda precisaria se desenvolver através de políticas propriamente laborais.

\section{Intermezzo: o 'dever de cuidar' e a 'cultura do sacrifício pessoal'}

Em vários aspectos relevantes, os trabalhadores que atuam à margem do staff, regidos por contratos independentes, podem ser considerados desprotegidos em um nível comparativamente mais grave. Como persistem dúvidas sobre a forma precisa de qualificar juridicamente a natureza da relação de trabalho que os rege, as proteções que lhes são aplicáveis não são, por isso, evidentes, o que "certamente torna aqueles que pertencem à categoria móvel de contratados independentes mais vulneráveis" (Brino, 2018, p. 157).

Um desses aspectos é relativo à seguridade social ${ }^{15}$. Os horistas contratados pela OIM são cientificados em seus contratos que eles serão protegidos contra acidentes de trabalho e doenças profissionais pelo Plano de Compensação (Compensation Plan) da entidade. Embora isso esboce o compromisso da organização com os contratantes, uma cláusula subsequente chama a atenção: o contrato não dá direito de participação no Fundo Conjunto de Pensões do Staff das Nações Unidas (UN Joint Staff Pension Fund, UNJSPF). Esse fundo, que diz respeito a um plano interagencial de pensão criado pela Assembleia Geral das Nações Unidas, ainda em 1949, para prover aposentadoria e benefícios por morte, invalidez

\footnotetext{
15“[...] a ONU parece não considerar consultores ou contratados individuais como funcionários ou agentes. Isso também é evidente se considerarmos o campo específico de saúde e segurança. A ONU 'não fornece ou organiza cobertura de seguro de vida ou de saúde para consultores e contratados individuais, e consultores e contratados individuais não são habilitados a participar dos esquemas de seguro de vida e saúde fornecidos pelas Nações Unidas para seus funcionários"' (BRINO, 2018, p. 178).
} 
ou outros, ao pessoal que atua na ONU e suas agências (ARVIZU, 2011, p. 176), pertence exclusivamente aos membros do staff 16 .

Pode-se admitir que direitos previdenciários são notadamente espinhosos, uma vez que a sua titularidade pressupõe uma contraprestação, e esta deveria ser definida equitativamente a partir de um detalhado conjunto de regras de contribuição. Entretanto, é possível descer a exemplos menos densos e mais corriqueiros, a partir dos quais se poderia dizer que o não reconhecimento em favor dos contratados móveis, p. ex, dos privilégios e imunidades que o direito internacional confere aos funcionários de agências internacionais (CAPONE, 2018, p. 474), seria a menor das preocupações. Os exemplos seguintes pretendem ilustrar como a força de trabalho predominantemente inexperiente - do pessoal non-staff recrutado em Boa Vista, como em outros cantos do mundo, requereria a assunção de um dever de cuidado em relação a eles; e esse dever seria não apenas ético, mas também jurídico (MATHIASON, 2013).

Em primeiro lugar, frise-se que a intervenção das agências internacionais em Roraima ocorre em um contexto de emergência humanitária relacionada à crise na Venezuela17. Na tipologia proposta por Väyrynen (1996), haveria basicamente dois tipos de emergências humanitárias, as violentas e as complexas. O primeiro tipo envolveria vítimas de guerra e fluxos de refugiados (deslocamento forçado), ao passo que o segundo incluiria situações de doenças e fome em larga escala. Não é

\footnotetext{
16 E mesmo eles (do staff) têm certas dificuldades de reivindicar os benefícios do UNJSPF, como atestam algumas demandas junto ao ILOAT (2019), p. ex., o caso S.G. v. IOM.

${ }_{17} \mathrm{O}$ Informe de Situação $\mathrm{n}^{\circ} 6$ (novembro de 2019), relativo à Resposta Humanitária à crise venezuelana refere que "A Organização Internacional para as Migrações (OIM) e a Agência da ONU para os Refugiados (ACNUR), anunciaram em 13 de novembro um Plano de Resposta Regional de $\$ 1.350$ milhões de dólares para assistir os refugiados migrantes venezuelanos, assim como as comunidades de países latinoamericanos e caribanhos que os acolhem". Disponível em: https://reliefweb.int/report/venezuela-bolivarian-republic/venezu ela-respuesta-humanitaria-informe-de-situaci-n-no-6. O Informe também afirma que o Secretário-Geral Adjunto das Nações Unidas para Assuntos Humanitários e Coordenador de Emergência, Mark Lowcock, tem acompanhado de parte o caso da Venezuela.
} 
exagero destacar que a migração venezuelana contém claramente elementos desses dois tipos.

Um postulado da emergência humanitária é que sejam oferecidas respostas rápidas e efetivas por parte do pessoal que atua na linha de frente da intervenção. As demandas emergenciais, em certos casos, podem ter efeitos nocivos sobre os que tentam administrá-la: "a saúde mental de pesquisadores e trabalhadores de campo humanitários pode ser prejudicada pela exposição intensa às consequências físicas e psicológicas de emergências humanitárias complexas" (Reed, 2002, p. 2). Citando Jonathan Shay, Holly Reed recorda o "perigoso fenômeno" a que chamam de "transposição da linha de sanidade" (baseline creep), "o qual pode ocorrer quando os pesquisadores vão se acostumando gradualmente e, por isso, não conseguem se proteger emocionalmente dos horrores e riscos de trabalhar em ambientes perigosos com sujeitos que experienciaram atrocidades" (2002, p. 2).

É verdade que esses riscos são maiores para os funcionários de carreira, uma vez que trabalhadores non-staff não se vinculam a contratos por longos períodos. No entanto, suas jornadas diárias intensas são muitas vezes estressantes de um modo preocupante. O relato de pessoas que trabalharam como horistas para a OIM no posto de triagem para venezuelanos recém-migrados, poderia fornecer alguns indicativos disso.

O Posto de Triagem - PETRIG está sediado em uma área disponibilizada pelo Exército, contígua à $1^{\text {a }}$ Brigada de Infantaria de Selva e distante alguns quilômetros do centro de Boa Vista. Ele é gerenciado por um esforço logístico-humanitário formado pelo Exército Brasileiro e pelas organizações internacionais, em parceria com ONG's, no contexto da chamada "Operação Acolhida". A principal função do PETRIG é servir como um primeiro local para atendimento da comunidade venezuelana recémchegada, catalogando informações sobre o perfil dos imigrantes, esclarecendo dúvidas sobre a condição jurídica e os direitos básicos deles e 
fazendo os encaminhamentos necessários. No Posto, trabalham pessoas contratadas como horistas pela OIM, mas também contratados individuais do ACNUR e do UNFPA.

Os ambientes no PETRIG em que são feitos os serviços de triagem são tendas de grande porte, montadas e equipadas com centrais de ar para fazer frente ao clima abrasador de Roraima. A despeito das precauções adotadas, os relatos registram que o número de trabalhadores é maior do que a capacidade das tendas. Como consequência disso, algumas mesas de atendimento são montadas fora delas, expostas diretamente ao calor excessivo - há rodízio entre os contratados para alternar quem atenderá fora ou dentro. Segundo depoimentos colhidos, os próprios contratados assumem que se não usassem a parte externa para o atendimento, não conseguiriam dar conta da demanda diária.

Além disso, a alimentação fornecida pelos servidores militares no PETRIG é geralmente considerada ruim. Os bebedouros locais são compartilhados com centenas de pessoas que passam pelo atendimento diariamente, e por isso têm o aspecto mal-cuidado e são considerados antihigiênicos. Muitos dos contratados optam por levar a sua própria comida e garrafas de água mineral para o consumo próprio.

O trabalho dos consultores, que realizam atividades de pesquisa de campo junto à população migrante nas ruas, nos abrigos ou em ocupações, é considerado o mais exaustivo. De vez que trabalham mais expostos ao sol, a eles são fornecidos bonés e camisas em mangas compridas. Trabalhos itinerantes dão direito ao custeio de transporte (táxis), exigindo-se do contratado que apresente o recibo da viagem realizada. Contudo, alguns deles, pela comodidade, decidem deslocar-se até os locais de trabalho nos meios de transporte próprios (automóveis ou motocicletas). Uma opção para ser poupado do sol escaldante é trabalhar de madrugada: alguns cumprem jornada no aeroporto, após a meia-noite, auxiliando famílias migrantes a 
embarcar com segurança nos voos para outros Estados (no processo chamado "interiorização").

Todo esse pessoal trabalha diretamente com os migrantes, ouvindo suas histórias e tentando dar o melhor encaminhamento para os seus pleitos, de forma a ajudá-los a alcançar seus objetivos de vida. São levados, todo dia, a exercitar a empatia. Embora isso talvez pudesse demandar algum tipo de capacitação especial, não é de se estranhar que os contratados, mesmo reconhecendo os percalços da rotina laboral, narrem de modo predominantemente positivo as suas experiências. Uma das pessoas ouvidas relatou, de modo interessante, que a dedicação abnegada ao trabalho humanitário era estimulada por uma "cultura do sacrifício" alimentada no macroambiente interagências ${ }^{18}$. Pensar na nobreza do trabalho dedicado aos migrantes capturaria o foco e concentraria as expectativas dos trabalhadores em geral (staff e non-staff), de modo a que as agruras do contexto de emergência não se tornassem o elemento definidor da sua rotina e do seu ambiente de trabalho.

No entanto, se todos se irmanam na exigência por dedicação e altruísmo, perde sentido qualquer tratamento diferenciado aplicado às categorias de trabalhadores, sobretudo quanto aos distintos graus de cuidado que as agências possam ofertar a cada uma delas. Andrea de Guttry, a propósito, refere que o dever de cuidado das agências com o seu pessoal está diretamente ligado ao ideal de um meio ambiente de trabalho seguro "para todos":

O empregador tem o dever de agir com cuidado razoável para evitar e mitigar qualquer dano à saúde e segurança de seu pessoal. [...] Para cumprir esse dever, a organização internacional deve alocar recursos financeiros e humanos para garantir a saúde e a segurança no local de trabalho como uma questão prioritária, tomando medidas concretas e direcionadas para o cumprimento desta obrigação. Em qualquer caso, as medidas não devem ser

18 Essa cultura contrastaria frontalmente com um clima de ambição por cargos do staff (para os quais os contratados individuais têm preferência) que uma pessoa ouvida narrou existir na OIM, que gerava disputas e um ambiente menos colaborativo entre o pessoal nonstaff. 
discriminatórias e o pessoal não deve ser privado de proteção devido à natureza de seu contrato de trabalho com a Organização (v.g, funcionários temporários, consultores, etc.) (grigo nosso). ${ }^{19}$

Perguntadas sobre se o trabalho rotineiro (no PETRIG e em alguns abrigos de refugiados) poderia ser considerado insalubre a partir de critérios nacionais adotados por órgãos de fiscalização, uma pessoa ex-contratada respondeu positivamente, e outra não soube responder.

Como já foi dito, as normas trabalhistas nacionais não são aplicáveis nesses casos, mas os princípios gerais do direito o são, e é possível deduzir do direito internacional do trabalho - a partir de convenções da Organização Internacional do Trabalho, como a Convenção 155, de 1994 - princípios que obrigariam os empregadores em geral à promoção da segurança e da saúde dos trabalhadores no ambiente de trabalho. Não podendo a Delegacia Regional do Trabalho atuar como órgão fiscalizador, caberia à Unidade de Inspeção Conjunta das Nações Unidas (Joint Inspection Unit, JIU), sediada em Genebra, fazê-lo.

Conforme relatório de 2014 (JIU/REP/2014/8), essa Unidade de Inspeção Conjunta recomendou aos secretários executivos das agências do sistema ONU que revisassem suas políticas para o pessoal non-staff, tomando em consideração "o princípio da relação de trabalho [employment relationship principle], de acordo com as relevantes recomendações laborais da Organização Internacional do Trabalho", e que publicassem periodicamente relatórios sobre o uso desse pessoal tanto para seu gerenciamento interno quanto para o controle externo de órgãos governamentais ( $C f$. Recomendações 1 e 5 , in TERZI; FALL, 2014, p. 5).

Ainda de acordo com o relatório, as gestões executivas deveriam assegurar ao seu pessoal condições de trabalho decente, incluindo salário justo, benefícios e direitos sociais; que houvesse um mecanismo claro, justo e

${ }^{19} C f$. o Comentário ao $1^{\circ}$ Princípio Orientador relativo à Implementação pelas Organizações Internacionais de suas Obrigações de Dever de Cuidar de seus Funcionários Civis, in: de Guttry et alli, 2018, p. 486. 


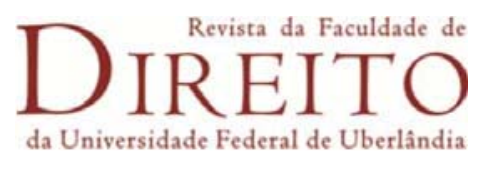

racional para a determinação de suas remunerações; e que os trabalhadores non-staff fossem devidamente informados do direito que têm ao acesso a sistemas de soluções de controvérsias, comitês de ética e ouvidorias ( $C f$. Recomendações 7, 10 e 12, in TERZI; FALL, 2014, p. 5-6).

O desafio posto é tornar efetivas as políticas e regras que buscam equilibrar a necessidade de que o pessoal em geral da ONU seja protegido pelos seus empregadores (dever de cuidar) e que esse mesmo pessoal aceite voluntariamente o desafio de se devotar aos desígnios do trabalho humanitário. Annalisa Creta (2018, p. 168), a respeito disso, expõe que

\begin{abstract}
Revisões recentes conduzidas pela Unidade de Inspeção Conjunta e por um Grupo de Trabalho de Alto Nível sobre como 'reconciliar o dever de cuidar do pessoal da ONU com a necessidade' de este permanecer e se entregar 'em ambientes de alto risco' confirmaram que, além de áreas críticas selecionadas que precisam de maior desenvolvimento e atenção, a principal questão em jogo, para garantir o dever de atendimento da ONU em face de seu pessoal, é a fiscalização do cumprimento, e a maior operacionalização, das regras e políticas existentes, de maneira coerente e sistemática em todo o Sistema das Nações Unidas. (destaque no original)
\end{abstract}

As regras e políticas existentes, entretanto, não são apresentadas ou conhecidas suficientemente por aqueles a quem elas mais interessariam e deveriam cuidar. A falta de informações claras pode ser percebida já nos termos de referências que as agências utilizam para recrutar trabalhadores, que detalham atribuições e deveres, mas são lacônicas em relação aos direitos decorrentes do contrato ${ }^{20}$.

Os detalhes relacionados à implementação dos contratos com o pessoal independente, nas agências em Boa Vista, e como algumas práticas poderiam ser interpretadas à luz dos padrões e princípios aplicados às relações trabalhistas no âmbito nacional, são expostos no tópico a seguir.

${ }^{20} C f$., v.g., o termo de referência para recrutamento de Coordenador de Campo da OIM: https://robuenosaires.iom.int/sites/default/files/Vacancy/document/ToR_Coordenador\%20de \%20Campo\%200IM\%20Brasil\%20-\%20Roraima.pdf ; e o termo de referência para a contratação de motorista do UNFPA: https://brazil.unfpa.org/sites/default/files/vacan cies/Project\%20Driver\%20-\%20Boa\%20Vista.pdf ; ambos sequer especificam, p. ex., o valor da remuneração e a carga horária. 


\section{As condições de trabalho dos contratados em face dos padrões laborais nacionais}

Há um princípio segundo o qual as organizações do sistema das Nações Unidas devem oferecer sempre padrões de emprego que não sejam menos vantajosos, em termos de direitos, do que aqueles existentes no mercado de trabalho do país em que elas estiverem atuando. Observado o princípio, não deveria haver, em qualquer hipótese, relações de trabalho que desrespeitassem padrões mínimos estabelecidos pelas leis e pela política trabalhista no país anfitrião (TERZI; FALL, 2014, p. 25).

Diversos aspectos gerais e específicos dos contratos de trabalho das agências em Roraima chamam a atenção daqueles que estão acostumados com os padrões trabalhistas brasileiros. Apenas alguns desses aspectos serão referidos aqui, supondo-se que sejam suficientes para ilustrar por que as novas oportunidades de trabalho trazidas pelas agências não são imunes a críticas.

Sem dúvidas, deve-se começar pelo contrato por hora de trabalho utilizado amplamente pela OIM em Roraima. Aos aplicantes selecionados, é apresentada, em inglês, uma proposta padrão sob a forma de um Special Short Term Hourly Contract. A proposta contratual é sintética e direta. Nela, finalmente constam o número máximo de horas que se poderá trabalhar (240 horas) e o valor da hora de trabalho ( $\mathrm{R} \$ 8,50)$. Embora seja fixado um período de tempo para o cumprimento das horas - equivalentes a 30 dias de trabalho, com carga horária de oito horas para cada dia -, a jornada de trabalho pode adequar-se às contingências da rotina. $\mathrm{O}$ contrato é invariavelmente renovado a cada mês.

Umas das cláusulas diz que o horário de trabalho seguirá conforme o acordado pelas partes, mas talvez este seja o único dispositivo que sugira que o contrato está aberto à negociação. As cláusulas principais são 
inflexíveis. Consta da parte final: "Se você aceitar este contrato, por favor assine a aceitação da oferta e a declaração ${ }^{21}$ ".

A hora trabalhada na OIM é a mesma, independentemente se o candidato trabalhar em escritório improvisado, nas ruas ou nos abrigos, durante o dia ou de madrugada, em dias da semana ou feriados. Uma pessoa ex-contratada revelou que lhe parecia intuitivamente injusto que a hora não fosse distinta para os que trabalham nos abrigos e nas ruas, à noite ou nos feriados, em comparação com os que trabalham no escritório, de dia e no expediente normal.

O contratado deve assinar uma planilha de frequência diariamente, que, revisada e assinada por um supervisor, serve como base para o cálculo da remuneração. As horas gastas no almoço não são computadas na planilha, e o repouso semanal não integra o cálculo da remuneração. A cláusula do contrato que dispõe sobre a remuneração diz expressamente: "Você receberá uma taxa, com tudo incluído [all-inclusive fee], de $\mathrm{R} \$ 8,50$ reais por cada hora”. Não é fornecido um contracheque impresso ou digital, apenas se deposita o valor na conta bancária indicada.

Até 2019, embora parecesse implicitamente convencionado que a carga horária diária seria de oito horas, os horistas se sentiam livres para exceder esse limite. Na prática, não existia teto remuneratório. Quanto mais se trabalhava, mais se recebia. Eram comuns, por isso, os casos de pessoas que trabalhavam nove, dez, ou mesmo doze horas ou mais por dia. O abuso das longas jornadas fez com que a OIM revisasse o modelo, muito embora a natureza do contrato permaneça ainda controvertida. As remunerações passaram a ser por valores fixos, pagos a cada duas semanas. Isso não tem impedido, contudo, que alguns trabalhadores façam jornadas extras, já que ainda se admite que as horas excedentes às 40 horas por semana sejam trocadas for folgas negociadas com a chefia.

21 No original em inglês, integralmente: "If you accept this contract, please sign the acceptance of offer and declaration below, in two copies, and return them to me keeping the third copy for your records". 
Esse contrato de horista, que se estima que envolveria mais de $80 \%$ do pessoal total da OIM em Roraima, estaria em claro desacordo com as leis brasileiras, pelo menos em alguns aspectos. Para citar os pontos mais evidentes: quanto ao descanso semanal, que não é remunerado, e quanto à remuneração do trabalho noturno, que não é maior que a do diurno. Outro ponto residiria na cláusula do contrato que diz que este pode ser rescindido antes de sua expiração, bastando que a parte avise por escrito com antecedência mínima de um dia. Segundo a Consolidação das Leis do Trabalho (art. 487, II), o aviso prévio para quem recebe pagamento a cada duas semanas, como os horistas da OIM, deveria ser de no mínimo 30 dias.

Os contratos convencionais por tempo fixado (fixed-term), usados por todas as organizações internacionais para o cargo de consultor, também não estão livres de discrepâncias com os padrões nacionais utilizados para o caso de férias, ajuda de custo ou sindicalização, por citar alguns exemplos.

Uma vez que esses contratos, em geral, não excedem um ano (shortterm), ainda que seja possível a renovação ao final ${ }^{22}$, não há que se falar em férias anuais, já que o preenchimento do período aquisitivo coincide com a resolução do contrato. Férias são, com efeito, uma prerrogativa do staff. Existe aos consultores individuais, em compensação, ajustes informais que permitem o gozo de folgas periódicas, como na OIM e no UNICEF. No entanto, essas folgas são obtidas, como se disse, à custa de jornadas esticadas.

Trabalhos itinerantes nas agências dão direito ao custeio de transporte (táxis), bastando que o funcionário apresente o recibo das viagens realizadas. Porém, alguns contratados em Roraima, pela comodidade, optam por deslocar-se até os locais de trabalho nos próprios meios de transporte (automóveis ou motocicletas), mas isso não será indenizado. Pessoas ouvidas

${ }^{22}$ Ao divulgar termo de referência para o cargo de motorista para os seus quadros de consultores individuais locais, em Boa Vista, o termo de referência do UNFPA indicava: "12 meses (inicialmente); renovável", https://brazil.unfpa.org/sites/default/files/vacancies/Project\%20Driver\%20-\%20Boa\%20 Vista.pdf 
expressaram que não consideram justo que não haja o pagamento de qualquer verba a título de auxílio-transporte nesses casos. Ainda, não fica claro quais acidentes ocupacionais são abrangidos pelo Plano de Compensação das agências, ou se eles precisam necessariamente ocorrer no "local de trabalho".

Os contratados fora do staff não têm o direito de integrar associações e federações sindicais como, p. ex., o Comitê Coordenador de Sindicatos e Associações Internacionais de Pessoal do Sistema das Nações Unidas (Coordinating Committee of International Staff Unions and Associations of the United Nations System) e a Federação Internacional dos Funcionários das Nações Unidas (United Nations International Civil Servants' Federation), ainda que essas associações tenham se tornado sensíveis à sua condição (Brino, 2018). Isso é ainda mais lamentável quando se verifica que as funções desempenhadas por essas entidades sindicais revertem em favor das próprias organizações, como registrado pelo ILOAT no caso $M$. J. $v$. UNESCO: "Como este Tribunal já enfatizou, é do interesse de uma organização internacional garantir que os sindicatos ou associações que representam seu pessoal operem em boas condições"23.

A impossibilidade de exercerem certos direitos trabalhistas que são ordinariamente reconhecidos, inclusive no direito comparado, deveria ser esclarecido previamente aos contratados locais. Em todo caso, pode-se assumir que esse dever de esclarecimento seria discricionário para as agências, porquanto dependa também da iniciativa dos próprios empregados de buscarinformações de seu interesse:

As organizações internacionais têm o dever de cuidar de seus
funcionários e devem fornecer regras e regulamentos claros, bem
como esclarecimentos, quando solicitados, mas não podem ser os
únicos responsáveis por todas as situações decorrentes de confusão
sobre essas regras. Os funcionários também têm a obrigação de se
informar e de solicitar esclarecimentos quando necessário, para
que o sistema possa trabalhar de maneira eficiente com a melhor

${ }^{23}$ Par. 6, Julgamento 3939, $125^{\text {a }}$ Sessão, 2018. 
vantagem da Organização e dos membros da equipe, em grupo ou individualmente (ILOAT, 2013).

Apenas uma pessoa, dentre as que foram ouvidas para esta pesquisa, informou que tinha buscado junto aos funcionários de recursos humanos informações e esclarecimentos de dúvidas decorrentes da celebração e execução do contrato.

O cotejo dos contratos independentes com os padrões trabalhistas locais pode parecer inútil, haja vista que, em última instância, as legislações e tribunais nacionais nada podem fazer contra as organizações e sua irrenunciada imunidade. Entretanto, por mais que as normas trabalhistas estatais não sejam aplicáveis àqueles contratos, é reconhecido que elas influem indiretamente, caso expressem ou reflitam um princípio geral do direito do trabalho, conforme decidido pelo ILOAT em 1995, no caso Kock, N'Diaye e Silberreiss v. European Patent Organisation (Reinisch, 2011).

A despeito disso, haveria para os membros non-staff, como um obstáculo intransponível, não apenas a falta de acesso às cortes nacionais, mas também ao contencioso administrativo internacional, de vez que o ILOAT não exerce sua quase-jurisdição em relação a casos que envolvam apenas os não-funcionários das organizações (Amerasinghe, 2009, p. 317, n. $53)$.

As querelas contratuais e eventuais violações de direitos ficariam então insolúveis, sem poder ser discutidas em qualquer foro imparcial. Porém, ainda existe um aspecto que não se pode olvidar: "[..] nenhuma relação de trabalho, seja permanente ou temporária, exclui per se a jurisdição de direitos humanos [...] a organização internacional não pode escapar de suas obrigações sob o direito internacional dos direitos humanos, que amparam cada vez mais os membros non-staff” (Macchi, 2018, p. 449). É conhecida a tendência de pesquisas que têm se concentrado em questões relacionadas à responsabilização das organizações internacionais pela violação das normas vinculantes de direitos humanos (Poli, 2018). 
O último capítulo pretende expor a incômoda ironia que há no fato de que as mesmas entidades internacionais que promoveram uma revolução copernicana no atendimento humanizado aos migrantes em Roraima, cobrando dos órgãos governamentais o respeito aos direitos humanos dos venezuelanos em condição de vulnerabilidade, tenham sido em alguns momentos negligentes diante de situações de risco aos direitos humanos (trabalhistas e securitários) dentro das suas próprias fileiras.

\section{Não é honesto criar uma força de trabalho vulnerável enquanto se defende direitos humanos e princípios internacionais do trabalho}

Os contratos em geral estão sob a sombra constante dos riscos de infrações. Os contratos trabalhistas das agências internacionais não são exceção. O fato de existirem demandas contra essas agências, tanto nos tribunais nacionais (a despeito da imunidade), quanto nos tribunais administrativos internacionais, atesta o quanto são comuns os casos de queixas nas experiências empregatícias junto às organizações internacionais. Não há nada de extraordinário, portanto, nas situações em que empregados não se conformam com a maneira como um contrato trabalhista é executado ou encerrado junto a elas.

Em todo caso, somente se considera crítico o caso se as infrações contratuais passam a se tornar, ou a se confundir, com violações à dignidade dos trabalhadores. Em muitos lugares, a falta de quaisquer mecanismos de inspeção regular sobre as organizações tende a permitir esse cenário, que já não será mais de mero descumprimento de regras contratuais, e sim de vulneração de direitos básicos.

Uma primeira tarefa aqui é definir quais direitos básicos estariam em risco nocenário que se buscou delinear. De vez que envolve agências do sistema das Nações Unidas, é conveniente utilizar como parâmetro para a aferição da violação de direitos uma fonte normativa da própria ONU. O 
tratado de direitos humanos de seu acervo que se ocupa dos direitos trabalhistas e de seguridade social é o Pacto Internacional dos Direitos Econômicos Sociais e Culturais (PIDESC), de 1966 - ratificado pelo Brasil por meio do Decreto n ${ }^{\circ} 591$, de 1992.

Serão abaixo transcritos os dispositivos que se considera pertinentes ao caso sob exame, para, em seguida, cotejá-los, cada um deles, com as situações laborais e contratuais levantadas nesta pesquisa, a fim de se concluir se um ou outro direito humano foi afrontado e de que maneira.

Art. $7^{\circ}$. Os Estados Partes do presente Pacto reconhecem o direito de toda pessoa de gozar de condições de trabalho justas e favoráveis, que assegurem especialmente: [...] b) À segurança e a higiene no trabalho; c) Igual oportunidade para todos de serem promovidos, em seu trabalho, à categoria superior que lhes corresponda, sem outras considerações que as de tempo de trabalho e capacidade; d) O descanso, o lazer, a limitação razoável das horas de trabalho e férias periódicas remuneradas, assim como a remuneração dos feridos.

Art. $8^{\circ}$. 1. Os Estados Partes do presente Pacto comprometem-se a garantir: a) $\mathrm{O}$ direito de toda pessoa de fundar com outras, sindicatos e de filiar-se ao sindicato de escolha, sujeitando-se unicamente aos estatutos da organização interessada, com o objetivo de promover e de proteger seus interesses econômicos e sociais. O exercício desse direito só poderá ser objeto das restrições previstas em lei e que sejam necessárias, em uma sociedade democrática, no interesse da segurança nacional ou da ordem pública, ou para proteger os direitos e as liberdades alheias; [...]

Art. $9^{\circ}$. Os Estados Partes do presente Pacto reconhecem o direito de toda pessoa à previdência social, inclusive ao seguro social.

$\mathrm{O}$ art. $7^{\circ}$, 'b', poderia servir ao exame da especial situação do pessoal non-staff que trabalha nas ruas e em postos de triagem e abrigos, conforme o enfoque seguinte:

1. Segurança: Ao trabalho itinerante, seria necessário um cuidado redobrado não apenas quanto à segurança pessoal com os riscos urbanos (violência, criminalidade, acidentes), mas também com a segurança emsentido laboral/ocupacional. Neste item, foram relatadas providências tomadas pelas agências para mitigar a penúria dos funcionários expostos ao sol e ao calor excessivo. 
2. Higiene: Aos que trabalham no PETRIG e em alguns locais, como no entorno da estação rodoviária de Boa Vista, em prédios públicos abandonados e ocupados por migrantes ou nos abrigos instalados pela Operação Acolhida e ONGs, são apontadas as condições invariáveis de higiene precária. A impressão é que essas condições são tomadas como inevitáveis pelos que as enfrentam. Não há qualquer compensação salarial pela insalubridade e a maioria das soluções práticas para enfrentá-la parte dos próprios trabalhadores.

$\mathrm{O}$ item 'c' do art. $7^{\mathrm{o}}$ poderia ser relacionado com a preferencialidade que as agências dão para a contratação de pessoal interno quando surgem novas vagas; os non-staff podem se tornar funcionários, e o staff nacional pode se tornar internacional. É uma forma de reconhecimento do mérito e das capacidades. Haveria apenas um ponto que demandaria atenção. Uma pessoa ex-contratada da OIM relatou que as oportunidades de ascensão ou mudança de regime para o pessoal non-staff, divulgadas nas agências, tem criado entre os contratados móveis um clima de competição não saudável, que estaria prejudicando, em certos momentos, o clima colaborativo que seria, segundo ela, essencial para o trabalho humanitário. Isso poderia ser talvez contornado com orientações e treinamentos adequados sobre o valor do trabalho em grupo.

O item 'd' do mesmo artigo é, sem dúvida, aquele que mais gera preocupações. Os pontos que ele aborda devem, com efeito, ser examinados à vista do contexto de emergência em que atuam os trabalhadores prómigração em Roraima. As agências seriam responsáveis por fazer com que as limitações próprias desse contexto não minasse o respeito a garantias mínimas no ambiente de trabalho. Em termos mais específicos, os itens enumerados no item 'd' poderiam ser examinados da maneira seguinte:

1. Descanso: As folgas a que têm direito os contratados são ajustadas de maneira informal e não são remuneradas. São obtidas, na maioria das vezes, através de trabalho extra. Seria necessária uma 
regulamentação do descanso a que têm direito, com vistas a um tratamento impessoal do assunto; e, caso existam regulamentos, eles deveriam ser tornados públicos e acessíveis a todos os contratados.

2. Lazer: Opções de lazer são asseguradas a todos os contratados, embora dependam, naturalmente, da disponibilidade de tempo para que possam ser usufruídas.

3. Jornada de trabalho razoavelmente limitada: Como foi dito, uma situação grave, ainda que causada involuntariamente, pode ser percebida na forma de execução dos contratos de horistas na OIM. Não havia anteriormente limites, de modo que muitas pessoas, por várias vezes, trabalhavam mas do que oito horas por dia. A fixação de um valor a ser pago periodicamente diminuiu enormemente os casos de jornadas excessivas, que, aliás, comprometiam o lazer e o descanso. Permanecem, contudo, situações de horas extras (não remuneradas) para fins de compensação por descanso ou nas agências com poucos trabalhadores e muitas demandas, como o UNICEF, o UNFPA e a ONU Mulheres.

4. Férias: As férias anuais são formalmente concedidas apenas aos funcionários (staff) das organizações. A maioria dos trabalhadores trabalha por contratos com termos fixados inferior a um ano. Não há, em razão da peculiaridade dos contratos, a previsão de férias aos nonstaff.

5. Remuneração dos feriados: Nas agências em geral, para os consultores, o trabalho realizado no feriado é remunerado de forma igual que nos dias normais, sem qualquer acréscimo na remuneração convencionada.

$\mathrm{O}$ art. $8^{\circ}$, que trata dos direitos humanos sindicais, deve servir para o debate da desagradável situação dos trabalhadores non-staff, que não podem se filiar às entidades sindicais nacionais, tampouco às entidades $\mathrm{e}$ federações internacionais para funcionários da ONU. 
Por fim, o direito à previdência social, previsto no art. $9^{\circ}$ do Pacto, exige mudanças efetivas para os contratados individuais. Eles não recolhem qualquer valor a título de contribuição previdenciária, para o Estado ou para a ONU, pelo que não terão direito ao regime previdenciário próprio das Nações Unidas, que é exclusividade dos funcionários, tampouco ao regime do Instituto Nacional do Seguro Social, válido para os trabalhadores regidos pela CLT.Todas as pessoas que foram ouvidas, a maioria jovens, afirmaram que não têm planos de previdência privada.

A partir de uma visão panorâmica, poder-se-ia afirmar que muitas situações vivenciadas pelos contratados por agências internacionais em Roraima envolvem, ainda que pontualmente, aqui e ali, violações de direitos humanos. No entanto, discutir eventual competência da jurisdição internacional de direitos humanos sobre essas situações extrapolaria os propósitos do artigo.

\section{Conclusão}

Encarregados da defesa e proteção de migrantes vulneráveis nas mais variadas dimensões da sua vida social e pessoal, os trabalhadores das organizações intergovernamentais em Roraima, sobretudo o pessoal nonstaff, precisam eles também de proteção especial. São mais de 200 pessoas que estão trabalhando localmente nas agências internacionais, e pelo menos 300 que já passaram pelo quadro de pessoal delas. A maioria hoje não integra osstaffs, e os poucos que integram, não pertencem ao staff internacional.

De um certo ponto de vista, todos eles (staff e non-staff)são vulneráveis, vez que executam seu trabalho no Brasil, mas não podem ser protegidos pelas leis, tribunais e órgãos fiscalizadores brasileiros, no tocante aos aspectos jurídicos contratuais de suas atividades laborais. O staff ainda 
pode recorrer aos tribunais administrativos sediados fora do Brasil, porém os non-staff, nem isso.

Tornadas cientes das situações de vulnerabilidade dos direitos humanos trabalhistas de seus contratados, as missões de emergência humanitária que se instalaram em Roraima deveriam tentar eliminá-las ou pelo menos atenuá-las e, nesse sentido, seria salutar que dessem maior atenção às novas políticas para non-staff que têm sido progressivamente implementadas pelas Nações Unidas. Caso essas missões se prolonguem por mais tempo, talvez coubesse uma visita da Unidade de Inspeção Conjunta da ONU ao Brasil. Com a visita in loco e utilizando sua experiência institucional, o órgão poderia propor algumas soluções viáveis para determinados problemas mais persistentes, antes que se transmutassem em intoleráveis violações de direitos humanos.

De qualquer sorte, a intenção deste artigo foi mais a de captar a atenção para uma conjuntura preocupante do que apontar culpados por violações concretas, de modo que um exame mais detido sobre a apuração de denúncias contra organizações internacionais deve cede lugar a uma reflexão mais geral sobre a triste ironia de um cenário de eventuais violações.

Antes de encerrar, é necessário ainda registrar que as pessoas ouvidas para este trabalho enfatizaram os investimentos feitos pelas agências em boas práticas no decorrer de 2019, com vistas a tornar o ambiente de trabalho mais saudável e seguro. Muitas das situações de risco que eram frequentes têm se tornado pontuais, o que, evidentemente, não deve desmobilizar a atenção que elas merecem. A reputação das organizações internacionais que atuam em defesa dos direitos humanos depende, afinal de contas, de que elas sejam capazes de fazer frente a vulnerabilidades e violações onde quer que elas se apresentem. 


\section{Referências}

AMERASINGHE, C. Ranjan Felix Jurisdiction of Specific International Tribunals. Leiden; Boston: Martinus Nijhoff Publishers, 2009.

ARVIZU, Sergio B. Designing Investment Policy to Ensure Long-Term Solvency: The U.N. Joint Staff Pension Fund. In: RAJKUMAR, S.; DORFMAN, M. C. (Eds.). Governance and Investments of Public Pension Assets: Practitioners' Perspectives. Washington DC: IBRD; World Bank, 2011.

BRASIL. Supremo Tribunal Federal. RE n. 578543. Relatora Min. Ellen Gracie, Relator p/ Acórdão: Min. Teori Zavascki, Tribunal Pleno, julgado em 15/05/2013, DJe-100.

Supremo Tribunal Federal. RE n. 1034840. Relator Min Luiz Fux. Julgado em 02/06/2017, Publicado em 30/06/2017.

Tribunal Superior do Trabalho. RO-147-69.2017.5.23.0000. Subseção II Especializada em Dissídios Individuais, Relator Ministro Alexandre de Souza Agra Belmonte, DEJT 13/12/2019.

BRINO, Vania. International Organizations as Employers: Examining the Duty of Care in the Light of the Different Forms of Employment Relationships. In: DE GUTTRY, Andrea; FRULLI, Micaela; GREPPI, Edoardo; MACCHI, Chiara (Eds.). The Duty of Care of International Organizations Towards Their Civilian Personnel: Legal Obligations and Implementation Challenges. Pisa; Florença: Springer, 2018.

CAPONE, Francesca. Victims' Right to Reparation and the Residual Application of Diplomatic and/or Functional Protection. In: DE GUTTRY, Andrea; FRULLI, Micaela; GREPPI, Edoardo; MACCHI, Chiara (Eds.). The Duty of Care of International Organizations Towards Their Civilian Personnel: Legal Obligations and Implementation Challenges. Pisa; Florença: Springer, 2018.

CIDH - COMISSÃO INTERAMERICANA DE DIREITOS HUMANOS. Resolução 2/18. Migração forçada de pessoas venezuelanas. $167^{\circ}$ período de sessões. Bogotá, 2018. Disponível em: https://www.oas.org/pt/cidh/decisiones/pdf/Resolucao-2-18-pt.pdf. Acesso em 12 jun. 2020.

CRETA, Annalisa. Implementation of the Duty of Care by the United Nations. In: de GUTTRY, A.; FRULLI, M.; GREPPI, E.; MACCHI, C. (Eds.). The Duty of Care of International Organizations Towards Their Civilian Personnel: Legal Obligations and Implementation Challenges. Pisa; Florença: Springer, 2018.

DE GUTTRY, Andrea. Comparative Analysis of International Jurisprudence and Relevant International Practice Related to the Duty of Care Obligations Incumbent on International Organizations Towards Their Mobile Workforce. In: DE GUTTRY, Andrea; FRULLI, Micaela; GREPPI, Edoardo; MACCHI, Chiara (Eds.). The Duty of Care of International Organizations Towards Their Civilian Personnel: Legal Obligations and Implementation Challenges. Pisa/Florença: Springer, 2018.

GUEVANE, Eleutério. OIM já faz parte do sistema das Nações Unidas. ONU News. 16 de setembro de 2016. Disponível em: https://news.un.org/pt/story/2016/09/1563141-oim-ja-fazparte-do-sistema-das-nacoes-unidas. Acesso em 12 jun. 2020.

ILOAT - INTERNATIONAL LABOR ORGANIZATIN ADMINISTRATVE TRIBUNAL. S.G. v. IOM. Julgamento $\mathrm{n}^{\circ}$ 4059. 06 Fev. 2019. Disponível em: https://www.ilo.org/dyn/triblex/triblexmain.fullText?p_lang=en\&p_judgment_no=4059\&p_la nguage_code=EN. Acesso em 12 jun. 2020. 
L. J.-S. v. European Patent Office. Julgamento 3213, 115 ${ }^{\text {a }}$ Sessão. 04 Jul. 2013. Disponível e: https://www.ilo.org/dyn/triblex/triblexmain.detail?p_lang=en\&p_ju dgment_no=3213\&p_session_id=115\&p_language_code=EN. Acesso em 12 jun. 2020.

MACCHI, C. The Transnational Dimension of International Organizations' Duty of Care Towards Their Civilian Personnel: Lessons from the Case Law on States' Extraterritorial Human Rights Obligations. In: DE GUTTRY, Andrea; FRULLI, Micaela; GREPPI, Edoardo; MACCHI, Chiara (Eds.). The Duty of Care of International Organizations Towards Their Civilian Personnel: Legal Obligations and Implementation Challenges. Pisa; Florença: Springer, 2018.

MATHIASON, Tiffany. Are You Part of the Global Workforce? An Examination of the "Duty of Care" to Business Travelers and International Assignees under the ILO Occupational Health and Safety Conventions and as Emerging International Customary Law. American University International Law Review, v. 28, n. 3, pp. 873-904, 2013.

NADER, Leonardo Soares; DUTRA, Samila Inácio. Implementation of the Duty of Care by the Organization of American States. In: DE GUTTRY, Andrea; FRULLI, Micaela; GREPPI, Edoardo; MACCHI, Chiara (Eds.). The Duty of Care of International Organizations Towards Their Civilian Personnel: Legal Obligations and Implementation Challenges. Pisa; Florença: Springer, 2018.

POLI, Ludovica. The Duty of Care as a Corollary of International Organizations' Human Rights Obligations. In: DE GUTTRY, Andrea; FRULLI, Micaela; GREPPI, Edoardo; MACCHI, Chiara (Eds.). The Duty of Care of International Organizations Towards Their Civilian Personnel: Legal Obligations and Implementation Challenges. Pisa/Florença: Springer, 2018.

REED, Holly. Research Ethics in Complex Humanitarian Emergencies: Summary of a workshop. Wasington DC: National Academy Press, 2002.

REINISCH, August. Contracts Between International Organizations and Private Law Persons. Max Planck Encyclopedia of Public International Law, Oxofrd University Press, v. VII, pp. 754-757, 2011.

TERZI, Cihan; FALL, Papa L. Use of Non-Staff Personnel and related contractual modalities in the United Nation System Organizations. Country case studies: Democratic Republic of the Congo, Haiti and India, JIU/REP/2014/8. UN, Genebra, 2014.

UNITED STATES SUPREME COURT. Jam v. International Finance Corp. Case n. 17 1011. 27 fev. 2019. Disponível em: https://www.supremecourt.gov/opinions/18pdf/171011_mkhn.pdf. Acesso em: 12 jun. 2020.

ULLRICH, Gerhard. The Law of the International Civil Service: Institutional Law and Practice in International Organisations. Berlim: Duncker \& Humblot, 2018.

UFRR e agências da ONU no Brasil inauguram Centro de Referência para Refugiados e Migrantes em Roraima. UFRR Noticias, 02 abr. 2018. Disponível em: http://ufrr.br/ultimas-noticias/4370-ufrr-e-agencias-da-onu-no-brasil-inauguram-centro-dereferencia-para-refugiados-e-migrantes-em-roraima

VÄYRYNEN, Raimo. The age of humanitarian emergencies. Paper prepared for the UNU/WIDER Conference on The Political Economy of Humanitarian Emergencies. 6-8 out. Helsinki, Finland, 1996.

Artigo recebido em: 30/04/2020.

Aceito para publicação em: 13/06/2020. 